\title{
PROLOGUE: IN THE ARCHIVES
}

S I was nearing the end of many months of research in the
New School's archives, I opened a box filled with bulletins and
announcements, a miscellaneous collection spanning over ninety years. ${ }^{1}$ In a folder labeled Early History, I found a typed memo, ragged and discolored, with no date or author's name. The paper looked old enough to belong in this file with other documents going back to the interwar period, but the memo itself referred to events that took place at a much later time.

Unable to make sense out of what I was reading, I was about to give up and turn to something else when I noticed a few faded words penciled in at the top of the first page: "Memo to A. J. who proposes writing a history of the School." A. J. was, of course, the legendary Alvin Johnson. An economist and journalist, he founded the New School for Social Research in 1919, together with other prominent intellectuals and philanthropists of the day, including the historians Charles A. Beard and James Harvey Robinson, and the editor in chief of The New Republic, Herbert Croly. Champions of academic freedom, they opened the New School as an act of protest against university presidents across the country who had forbidden professors to express themselves freely. Their primary target was Nicholas Murray Butler of Columbia University, who had fired two faculty members in 1917 for speaking out as pacifists during World War I while U.S. soldiers were fighting overseas. Several years later the two historians and Croly resigned from the New School, leaving its fate in the hands of Alvin Johnson.

If the memo I found was intended for Johnson, then its author was Agnes de Lima, his old friend and publicity director of the New School. Her style was unmistakable, an engaging blend of authority and charm, almost breezy at times, but never losing sight of the task at hand-in this case, to provide Johnson 
with an outline for his book. She promised to follow up with the necessary documentation.

De Lima had material going back to the early 1920s, with vivid examples of how Johnson had taken a failing "independent school of social science" and turned it into the country's preeminent school of adult education - to provide what he liked to call "the continuing education of the educated." By 1927, the New School had become the place to go to hear famous people lecture on politics and the arts, or recent developments in new fields of inquiry such as anthropology and psychoanalysis. In 1933, when Hitler rose to power, Johnson created within the New School the University in Exile, offering lifesaving visas and academic positions for nearly two hundred refugees. With this heroic achievement, he followed through with the founders' original idea of building a strong research faculty in the social sciences. Known officially, after 1934, as the Graduate Faculty of Political and Social Science, the University in Exile became a magnet for students interested in studying with eminent scholars who had fled the great universities of Europe.

Attached to the outline were fragments of a proposal, still in draft form, that Johnson had apparently written. Neither he nor de Lima ever finished the book. ${ }^{2}$ The only evidence I have that one of them, at least, was planning to do so was a notice published on November 23, 1959, in the New School Bulletin informing its readers that Agnes de Lima had just retired "in order to devote all her time-24 $24^{1 / 2}$ hours a day-to the completion of a book describing the history of the New School." ${ }^{3}$ The announcement appeared during the final weeks of the university's year-long celebration of three milestones: the fortieth anniversary of the New School for Social Research, the twenty-fifth anniversary of the University in Exile, and the eighty-fifth birthday of Alvin Johnson.

Despite his advanced age, Johnson was still going strong in 1959, and the university he had built was finally bouncing back after a long and rocky transition following his retirement. Honored guests stepped forward at every event to toast the first president, aspiring to match the eloquence of earlier tributes made by luminaries such as Thomas Mann, the German novelist and Nobel Prize laureate, who sang Johnson's praises in 1943 during Europe's darkest hours:

We are met to do honor to a man known wherever liberty is cherished, a man consecrated to the cause of intellectual freedom and dedicated to the principle of creative endeavor, a man who through his effort has made the New School for Social Research a place of abiding faith in liberal thought. Alvin Johnson, by his foresight and perseverance, has given refuge, hope, and home to hundreds 
of exiles now privileged to participate in the fight for freedom. . . . Long live Alvin Johnson!

Long live the University of Both Hemispheres. ${ }^{4}$

Alvin Johnson continued to lead an active professional life well into his nineties, writing prodigiously and keeping an eye on university affairs. What prevented him, therefore, or de Lima for that matter, from finishing the muchanticipated book? I believe they backed away six months after the big celebration, when the New School faced a serious crisis in leadership, making it difficult to complete the uplifting story they had started to tell on the few yellowed pages they had left behind.

Things began to deteriorate in June 1960, soon after the man Johnson had chosen to replace him stepped down as president. A political scientist and policy analyst, Hans Simons belonged to the generation of refugee scholars the New School had rescued "from the claws of fascism." Although they had their disagreements, Simons remained faithful to Johnson's vision of the school and consulted with him regularly. The next president, Henry David, was less solicitous. He preferred doing things his own way and, in the process, he nearly bankrupted the institution.

Johnson died in 197I at the age of ninety-six; de Lima three years later at eightyseven. Although they never followed through with their history of the school, de Lima spent the final years of her life organizing Johnson's papers for future researchers to use, filling dozens of boxes with hundreds of letters, speeches, and publications. She preserved countless newspaper articles and announcements as well that recorded the university's many accomplishments and those of its first president.

Over the years, Johnson maintained an active correspondence on the major issues of the day with politicians, jurists, intellectuals, and artists. He also wrote thousands of letters to raise money for the university, continuing to do so long after he retired. A master of the genre, in 1952 he playfully promised the New School's faithful friends that, with their next gift, they would receive a bound volume of his fund-raising letters, called The Compleat Beggar. ${ }^{5}$

Johnson published widely on economics, politics, and the role of education in a democratic society in scholarly journals and for the general public. He tried his hand at fiction as well. In his popular writing, he often used a deliberately folksy style that dripped with irony when he described his political opponents-for example, in his autobiography, written at the height of the McCarthy period, where he defiantly took aim at the "Philistines" in Washington. 
Although the New School has preserved many boxes of letters and other pertinent material, Johnson sent his official papers to Yale, a decision he tried to explain diplomatically, but the message was clear. In a mass mailing dated "spring 1967," Johnson wrote:

Recently, the Yale University Library has invited me to place [my] papers in the Beinecke Rare Book and Manuscript Library in New Haven, which is specially equipped to care for archives entrusted to it. This I am very glad to do since the New School for Social Research, where my papers might properly belong, has no archival facilities at present and is growing so fast that any space that becomes available is promptly pre-empted for classrooms and offices.

I am therefore calling on my friends and colleagues to help me gather the material together. If by any chance you have preserved any of the letters or articles with which I was wont to afflict you, won't you send them to my friend, Agnes de Lima, whom I have asked to organize and classify the material and then send it on to Yale. ${ }^{6}$

Others followed Johnson's example. Joseph Greenbaum, dean of the Graduate Faculty, sent the papers of the New School's refugee scholars to a special archive in Albany, at the State University of New York. ${ }^{7}$ And the political philosopher, Hannah Arendt, who joined the faculty after the war, sent her papers to the Library of Congress. By the mid-1980s, whatever documents remained in the New School's archives were in tatters, the predictable result of years of neglect and the object today of a major campaign to preserve them.

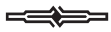

Johnson wrote with exuberant pride about the early years at the New School. His descriptions literally jumped off the page, often teasing readers with an irreverent anecdote but never letting them forget that he was writing about some of the most significant scholars, politicians, and artists of the day. At the end of his proposal for the book he never completed, Johnson attached a short sketch of life at the New School during the late I920s, signaling, in a few sample paragraphs, that he planned to write an unconventional history of his decidedly unconventional school. The incidents he described took place in Chelsea, where the New School held classes before moving to Greenwich Village in 1931:

In The New York Times of April 3, 1927, we find an item on Senator [William] Borah, who "often pictured as Jovian and cloud wrapped, seemed entirely human 
here the other night when he attended a meeting of the New School for Social Research in a small back room of a basement bookshop. He was cloud wrapped at that, but the clouds were only tobacco clouds. He sat smoking . . . while a group of kindred spirits plied him with questions."

The New School lecturers in those days included names still well known today. A sampling: Clarence Darrow, John Dewey, Walter Lippmann, [Zachariah] Chaffee ... taking part in a series on "Freedom in the Modern World." ... Eva Le Gallienne gave benefit performances of “The Master Builder” in Feb.'27.

One incident disturbed the scholarly calm of the little courtyard or campus on West 24th Street. Horace Kallen in his bachelor days had rented from the New School an apartment on the top floor of one of the houses. One night an intruder broke in. It was a hot summer night and Horace Kallen's feet protruded beyond the sheets. The intruder with a strange sense of humor, the press reported, stopped and tickled the professor's toes. Horace Kallen, alarmed, less for himself than for the safety of his sister lying ill in the adjoining room, leaped on the burglar, grappled with him, and triumphantly threw him out of the third-story window. By that time, the place was in an uproar. Fred Grote, the superintendent, summoned the police, who came in droves to search for the culprit, who was nowhere to be found. But Fred's little fox terrier set up a frightful din outside some shrubbery planted against the wall of the courtyard. The police drew out the shrinking fugitive who was bleeding profusely from a severed ear. A German newspaper, reporting the incident declared, "Der Herr Professor biss dem Dieb das Ohr ab" (The distinguished professor bit the thief's ear off $).{ }^{8}$

Ending the sketch playfully with a quote in German permitted Johnson to note, as if only in passing, that his "Herr Professor" had an international reputation, a distinction Kallen shared with other scholars and artists who lectured regularly at the New School. Johnson could safely assume in 1959 that his readers would recognize Kallen's name. The philosopher was widely known for having introduced the term cultural pluralism into scholarly and popular debates during the first quarter of the twentieth century. According to Kallen, ethnic diversity strengthened democracy in the United States by replenishing the nation's cultural and economic resources. His own biography was a case in point: The son of an Orthodox Jewish rabbi, his family emigrated from Silesia in 1887 , when he was five years old, following the expulsion of Jews and Poles from the expanding German Empire. Raised in a strictly religious home where the family spoke and read several languages, Kallen went on to become a major figure in American philosophy and in the nation's growing community of secular Jews. 
In the outline itself, Johnson described the New School as "a center where the intelligent layman and the specialist were able freely to examine together the vast and frequently bewildering issues of the time." It attracted people, he explained, who wanted to learn about the complexities of contemporary society and culture from different perspectives. The New School was one of the few places where they could do so:

In the days when the teaching of the social sciences was languishing in universities and colleges throughout the country, the New School boldly pursued those studies, including the revolutionary discoveries in psychology, psychoanalysis, and anthropology. Similarly, in the fields of modern art, modern music, modern dance, the New School was among the pioneers in offering courses and workshops directed by leading artists and critics.

And it taught these courses during the evening, making it possible for working people to attend.

But that was not all. What defined the New School above everything else was "its continuing struggle," Johnson proclaimed, "against discrimination in education, signalized both by its dramatic rescue of foreign scholars from the hands of dictators and its stated charter provisions that no consideration whatever be given in the appointment of faculty members to race, creed, or other irrelevancies. The dramatic story-one of national significance — of the University in Exile will be here given in illuminative detail!"

Johnson planned to open each chapter with an overview of the period, and then show how the New School organized debates around the important issues of the day with leading intellectuals, artists, and politicians who dared challenge conventional wisdom from the left and the right-like the "Jovian" Senator Borah. In addition to describing the rise of fascism in Europe and the founding of the University in Exile, Johnson intended to focus on the events following each of the two world wars, when "Red scares" threatened democratic institutions throughout the nation. The proposal spoke of comparing the impact on the New School in the early I920s of New York State's Committee to Investigate Seditious Activities, popularly known as the Lusk Committee, with that of the House Un-American Activities Committee in the late I940s and I950s. On both occasions, government agents sat in on classes and interviewed members of the administrative staff about the political activities of the faculty.

The book, Johnson continued, would describe the changing "spirit of the times" between 1919 and 1959 and the ways the New School responded. After World War I, during the first Red scare, students lost interest in "social issues." 
They preferred courses in psychology, modern literature, modern art, and modern music, "all reflected in the New School curriculum." But the faculty did not abandon social issues entirely. They continued offering courses on such provocative subjects as the Communist Revolution. Did the Lusk Committee try to close these classes down? And if so, how did the New School respond?

With the Great Depression, interests changed. During the 1930s, students clamored for courses on the failing economy and the rise of dictators across Europe: "The New School's answer was the founding of the University in Exile [which gave] great impetus ... to social science teaching throughout the country." When the United States entered the war, the New School "not only continued its rescue of foreign scholars, strengthening its function as a center of international scholarship, [it also] opened up new courses and workshops in international affairs."

After Germany fell and the Soviet Union gained control over Eastern Europe, a new wave of hysteria swept across the United States and into the nation's universities. Few academic institutions distinguished themselves during the McCarthy period, and the New School was no real exception. Although it weathered those years honorably when compared with many others, it too bowed to political pressure. Had Johnson spoken frankly about the period, he would have had to discuss the compromises his successors made over his vigorous objections.

Finally, Johnson planned to include portraits of some of the "dominant personalities" who had taught at the New School, among them such "world famous figures" as the French philosopher Jacques Maritain and the British political theorist Harold Laski. He also intended to quote from editorials "reflecting the school's philosophy," reconstruct faculty seminars and class discussions, and draw on other "human interest material." As Johnson envisioned it, his history of the New School would "truly [be] a mirror of the times and throw fresh light on contemporary American culture"-but the light it would throw, he must have been thinking, would not always be flattering.

Johnson could have ended his book with his retirement in 1945 when the New School was still at the height of its fame, praised the world over for having saved the lives of nearly two hundred scholars and with them the humanistic traditions of Europe. But that would not have been very generous. As his contribution to the anniversary celebrations, he would bring the story up to date. Or at least so he intended, until he abandoned the project entirely, for reasons I hope one day to discover. In the meantime, I can only speculate. 
The first book-length history of the New School was published in 1986. Written by Peter Rutkoff and William Scott, the study focused on the heyday of the university when Johnson was president. It then moved briskly over the post-Johnson years and stopped in the early 1980s. A second book, by Claus-Dieter Krohn, came out in West Germany in 1987 and was translated into English in 1993. Written for scholars interested in the Weimar and Nazi periods, Krohn looked exclusively at the University in Exile. Since the 1980s, a number of other works have appeared on intellectuals in New York during the interwar period and the Hitler years that also include extensive discussions of the social scientists, philosophers, and artists who taught at the New School. ${ }^{9}$

A Light in Dark Times offers a fresh look at the early history of the New School for Social Research without shying away from moments that complicate the familiar narrative. It then turns to the post-Johnson years, which others have essentially ignored, taking the story up to the beginning of the twenty-first century. In these later chapters, I focus primarily on the precarious fate of the Graduate Faculty in an institution that lacked the resources it needed to support it adequately.

The New School for Social Research has changed a great deal since the end of the twentieth century, symbolized, in part, by its decision to change its name, first to New School University, then to the New School tout court, at which point the Graduate Faculty adopted the institution's original name. Known today as NSSR, the old University in Exile as a champion of academic freedom and human rights and as scholars of engaged social research. Colleagues affiliated with other parts of the university firmly lay claim to the New School's legacy as well, adding pointedly that the university owes its place in history primarily to the role it has played as a pioneer in adult education.

A Light in Dark Times examines these overlapping narratives through the "incidents and stories" that hide behind the idea of the New School. To quote Hannah Arendt:

I have always believed that, no matter how abstract our theories may sound or how consistent our arguments may appear, there are incidents and stories behind them which, at least for ourselves, contain in a nutshell the full meaning of whatever we have to say. Thought itself ... arises out of the actuality of incidents, and incidents of living experience must remain its guideposts by which it takes its bearings if it is not to lose itself in the heights to which thinking soars, or in the depths to which it descends. ${ }^{10}$ 
In the spirit of Johnson's book proposal, $A$ Light in Dark Times unfolds against the backdrop of the political upheavals that marked "the short twentieth century": ${ }^{11}$ World War I and the first Red scare; the rise of Hitler and World War II; the McCarthy years; the student protests during the Vietnam War; and the downfall of communism in Eastern Europe. At times, colleagues' stories take us beyond the walls of the institution itself: to Washington, D.C. during the First and Second World Wars, to Germany and England in 1933, to Nazi-occupied Europe during World War II, and to Soviet-dominated Eastern Europe during the Cold War period.

The people who appear on the pages of this book are formidable figures, with strong opinions about what the New School stands for and how or whether the university should change. Johnson, however, towers over everyone else. Without his vision and entrepreneurial imagination, the New School would have folded in the early 1920s, its impact reduced to a footnote in history.

In moments of reverie, I imagine Johnson still inhabiting the walls of the New School's buildings, like the lares and penates he read about as a boy, those legendary house gods of ancient Rome who protected the occupants of family dwellings. An avid student of Latin and Greek, Johnson drew on his classical education regularly to strengthen an argument or to entertain. It takes only a small leap of faith to believe that he continues to watch over the New School family and to meddle, when necessary, to keep his idea of the university alive as he persisted in doing long after he had retired. 



\section{A LIGHT IN DARK TIMES}


